\title{
Design and Preliminary Test on the Integration of Weather Data in ECDIS for Marine Navigation
}

Shwu-Jing Chang

Associate Professor, Department of Guidance and Communication, National Taiwan Ocean University, Keelung, Taiwan, R.O.C.

Follow this and additional works at: https://jmstt.ntou.edu.tw/journal

Part of the Electrical and Computer Engineering Commons

\section{Recommended Citation}

Chang, Shwu-Jing (2001) "Design and Preliminary Test on the Integration of Weather Data in ECDIS for Marine Navigation," Journal of Marine Science and Technology. Vol. 9: Iss. 1, Article 3.

DOI: 10.51400/2709-6998.2431

Available at: https://jmstt.ntou.edu.tw/journal/vol9/iss1/3

This Research Article is brought to you for free and open access by Journal of Marine Science and Technology. It has been accepted for inclusion in Journal of Marine Science and Technology by an authorized editor of Journal of Marine Science and Technology. 
Design and Preliminary Test on the Integration of Weather Data in ECDIS for Marine Navigation

Acknowledgements

The author would like to thank Mr. K. C. Dai for his assistance in programming. 


\title{
DESIGN AND PRELIMINARY TEST ON THE INTEGRATION OF WEATHER DATA IN ECDIS FOR MARINE NAVIGATION
}

\author{
Shwu-Jing Chang
}

Keywords: Electronic Chart, weather, ECDIS.

\section{ABSTRACT}

The incorporation of marine weather information into Electronic Chart Display and Information System (ECDIS) has become a major issue common to international organizations such as IMO, IHO, and WMO. It is believed that this will further enhance the effectiveness of ECDIS as a tool of decision support to mariners for safe and efficient navigation. This paper first identifies essential items of marine weather information to be integrated into ECDIS. The data structure, formats, and symbology for the display and updating of weather data in ECDIS are then proposed according to related international standards. Potential use of weather data in ECDIS for route planning and monitoring is also discussed. Preliminary test by partial implementation in an ECDIS is performed to confirm the feasibility of this proposal.

\section{INTRODUCTION}

Electronic chart display and information system (ECDIS) is a navigation information system designed to enhance navigation safety. With ECDIS, mariners can have a selectable integrated display of information from an electronic navigational chart (ENC) database, navigation sensors, or other sources. ECDIS also provide mariners with route planning functions, such as editing waypoints/legs on the chart, checking the route against any danger or restriction depicted in the ENC database, and generating alarms accordingly. For ships at sea, ECDIS provide further route monitoring functions that keeps checking the current ship position and motion with respect to the preplanned route, ENC database and sensor information (such as radar targets) for any possible danger. Since the weather and sea state has significant effect on the safety at sea, the incorporation of meteorological and oceanographic information into ECDIS has become an issue of major concern to Inter-

Paper Received July 23, 2000. Author for Correspondence: Shwu-Jing Chang.

*Associate Professor, Department of Guidance and Communication, National Taiwan Ocean University, Keelung, Taiwan, R.O.C. national Maritime Organization (IMO), International Hydrographic Organization (IHO) and World Meteorological Organization (WMO). It is believed that this will further enhance the effectiveness of ECDIS as a tool of decision support to mariners for safe and efficient navigation. It will also promote cost effectiveness of shipping and better protection of the environment.

From literature and web search, it is found that, attempts to integrate weather data and electronic chart system are still limited to either overlaying the weather data for display on top of the navigational chart, or the calculation of speed loss along the route. The weather data can be in graphics, satellite imagery, or utilizing WMO's GRIB file format for the display, look ahead and animation of weather forecast. For example, in a weather wizard program recently developed by Transas company, currents and weather conditions (wind, wind induced waves and swell) are incorporated for the calculation of ship's speed loss, so that mariners can choose among their route plans for an optimum one.

To exploit the potential of integrating weather data into ECDIS, this paper first identifies essential items of marine weather information to be integrated into ECDIS. The data structure, formats, and symbology for the display and updating of weather data in ECDIS are then proposed according to related international standards. Potential use of weather data in ECDIS for route planning and monitoring is also discussed. Preliminary test by partial implementation in an ECDIS is performed to confirm the feasibility of this proposal.

\section{WEATHER DATA FOR NAVIGATION}

There are two major incentives to incorporate weather data in ECDIS. One is to support the route optimization for navigation efficiency. The other is to increase navigation safety by avoiding areas of severe weather. For the former, tidal and surface currents, wind, waves, and swell data should be available to ECDIS for the calculation of ship's speed loss. For the latter, meteorological warnings such as those available from GMDSS (Global Maritime Distress and Safety 
Table 1. Object and attributes for weather data

\begin{tabular}{|c|c|c|c|c|}
\hline & Object Classes & Geometric Primitive & attributes & Update type \\
\hline 1 & Station report & point & $\begin{array}{l}\text { wind speed \& direction, weather, sky cover, MSL pressure, } \\
\text { temperature }\end{array}$ & file \\
\hline 2 & Isobars & line & pressure value & file \\
\hline 3 & High pressure & point & central pressure, direction \& speed, forecast & file, object \\
\hline 4 & Low pressure & point & central pressure, direction \& speed, forecast & file,object \\
\hline 5 & fronts & line & category: warm, cold, occlusion; direction & file, object \\
\hline 6 & Tropical cyclones & point & $\begin{array}{l}\text { max. wind speed/force, radius (force } 10 \text { or } 7 \text { ), hemisphere } \\
(\mathrm{N} \text { or } S \text { ), direction \& speed, forecast }\end{array}$ & $\begin{array}{l}\text { object \& } \\
\text { attribute }\end{array}$ \\
\hline 7 & Cyclone track* & line & time of arrival at a point, direction $\&$ speed & object \\
\hline 8 & Alert area** & polygon & category of met.alert, cautionary notes & object \\
\hline 9 & area bulletin & polygon & wind, weather, visibility, wave & Attribute \\
\hline
\end{tabular}

* Collection objects C_AGGR can be used to aggregate all the objects related to a tropical cyclone.

** Collection object C_ASSO can be used to associate the alert area to the tropical cyclones or fronts.

System) should be integrated into ECDIS as a dynamic database in addition to navigational charts.

At present, reception of Maritime Safety Information (MSI) is mandatory under the GMDSS for all SOLAS class vessels (i.e. over 500 tons). The MSI is broadcasted via NAVTEX and INMARSAT SafetyNET service. According to the Joint IMO/IHO/WMO Manual on MSI, meteorological warnings and forecasts for the high seas shall include storm warnings, synopsis, and forecast. Storm Warnings part of the MSI include: type of warning (gales, storms and tropical cyclones); date and time of reference; type, central pressure, location, and movement of disturbance (e.g. low, hurrican, etc.); extent of affected areas; wind, sea, and swell conditions in the affected areas. The synopses shall have the following content of items: date and time of reference; major features of the surface weather chart; movement of significant pressure systems and tropical disturbances; central pressure and/or intensity; movement and changes of intensity for each system; significant fronts, highpressure centers, troughs and ridges. The forecasts shall have the following contents of items: valid period of forecast; designation of forecast area; wind speed of force and direction; visibility (if less than 6 nautical miles); ice accretion (if applicable); waves.

\section{INCORPORATION OF WEATHER DATA INTO ECDIS}

\section{ECDIS Related Standards and Terms}

For an electronic chart system to be certified as an ECDIS, it should meet the minimum functional and performance requirement as specified in IMO resolution A.817(19) on "Performance Standards for ECDIS". ECDIS operates on a database called system ENC or
SENC. SENC consists of data transformed by ECDIS from the official ENC released by hydrographic offices, plus ENC updates and other data added by the mariner or from other sources. Contents, structure and format of ENC are specified in ENC product specification included in IHO S-57 edition 3 [2]. Presentation (decoding and symbolization) of the SENC on the ECDIS display is specified in IHO S-52 [3], appendix 2 "Colour and Symbol Specification for ECDIS". In the theoretical data models of S57, real world entities are defined as a combination of descriptive and spatial characteristics. The descriptive information and the geometry (the information of shape and location) are defined in terms of feature objects and spatial objects, respectively. There are four types of feature records: geo, meta, collection and cartographic. An object may have attributes and may be related to other objects. In order to facilitate the efficient processing of ENC data, ENC of different compilation scales are categorized into six navigational purposes (intended usage), and the geographic coverage of a given usage is split into cells. Object classes and attributes for time-varying current, tide and tidal stream data are already specified in IHO S57, ed.3. These items will not be discussed further here.

\section{Data Encoding, Transfer and Updating}

Based on these standards, especially IHO S57, objects and attributes for encoding and updating weather information in ECDIS are proposed as listed in Table 1. If the entire surface weather chart (including the station report and isobars) is to be incorporated, large amount of spatial and feature objects will be required to encode the information. These objects are updated (actually replaced) altogether regularly. Therefore, to transfer and update them in an efficient way, it is proposed to 
group them into a cell file and replace the whole cell for updating. In case only major features of surface weather chart (e.g. high and low pressure centers, significant fronts, such as those available from NAVTEX) are required or available, they may be updated (inserted, modified, or deleted) in an object-based way either automatically or manually. Surface prognosis and analysis can be treated in the same way and differentiated by using an attribute "forcst" indicating the hours of forecast. The time and date of reference can be encoded with "TIMSTA" (time start) attribute, and the valid period can be defined by adding "TIMEND" (time end). "SORIND" can be used to encode the source of the information. Cautionary and explanatory notes can be encoded with "INFORM" or "TXTDSC"(textual description). As for the routine weather and sea bulletin data, which could be provided as area encoded information, the meteorological area and sub-areas should be encoded into SENC of ECDIS. Only the attributes associated with these MET. areas are updated with the transmitted weather information. The numbering of updates as specified in the S57 ENC product spec. is limited to 3 digits, which is definitely not suitable for the frequent update of Met. info. Besides, met. info. could be independent of the navigational usage of ENC base cells. Therefore, there should be a separate product specification for weather data in S57, specifying the file naming, updating, application profiles, and the use of object catalogue for met. data.

\section{Symbolization and Data Presentation}

Meteorological and oceanographic MIO data should follow WMO symbology. For example, surface station report can be plotted in the so called "station model" at the point location of station. This can be easily implemented in S52 presentation library (PL) with a conditional symbolization procedure for ECDIS display. The station symbol is a combination of the symbols for the various attribute classes listed in Table 2 , while the symbol of each attribute class depends on the actual attribute value.

\section{Integration and Use of Data}

For route planning, forecast or predicted data are used. Weather data such as wind, wave (swell), and current can be used to calculate ship's speed loss for each leg of the preplanned routes in ECDIS. Mariners can thus select the most efficient route and get more accurate ETA (estimated time of arrival) or modify the route for a safer voyage.

For route monitoring with ECDIS, predicted weather conditions that might be beyond own ship's
Table 2. Symbology for station report

\begin{tabular}{|l|l|}
\hline Attribute class & Symbol \\
\hline Wind & One wind arrows for each wind speed code \\
& Oriented according to the wind direction \\
\hline Present weather & Weather symbols(synop code ww=00-99) \\
\hline Sky cover & Ntation model : \\
\hline MSL pressure & Numeric(same as those used for soundings) \\
\hline temperature & Numeric(same as those used for soundings) \\
\hline
\end{tabular}

Table 3. Symbology for Meteorological Objects

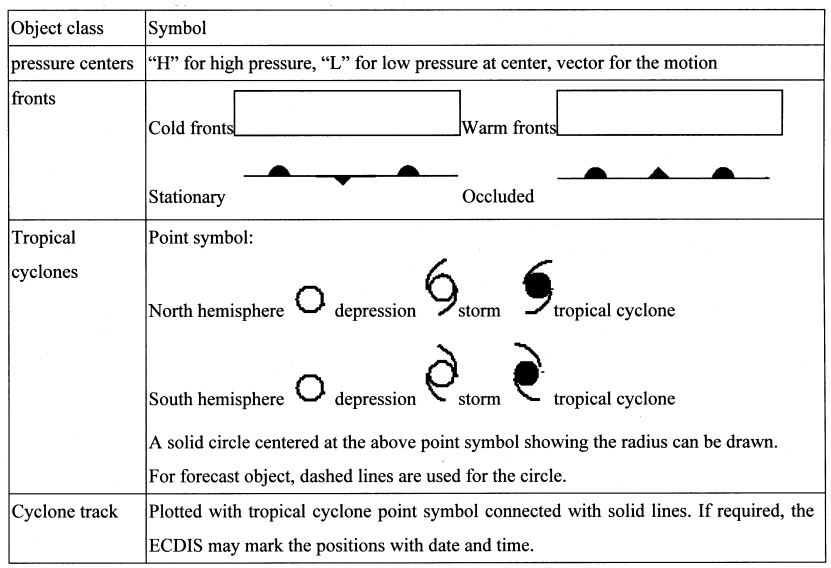

endurance (threshold values set by mariners) can be highlighted or set to generate alarms. ECDIS can then provide mariners with various tools as decision support for navigation safety. For example, from the tropical cyclone and cyclone track, navigable and dangerous semicircles can be identified, so that a suitable evasive action can be taken. From the movement of the storm relative to own ship, the course and speed to be taken to achieve a maximum CPA (closest point of approach) can be calculated. The level of threat can then be estimated by comparing the CPA with the radius of the storm.

\section{PRELIMINARY TEST RESULTS}

As a preliminary test, objects and symbolizations for tropical cyclone and fronts (See Table 3) have been implemented into an ECDIS system developed on windows NT with Visual $\mathrm{C}^{++}$. Results are shown in Fig. 1 and 2. Please note that data in these figures are only for feasibility test and illustration on symbology. In this test, complex line styles are designed for cold front and warm front. Direction of the front symbol is determined by the line direction. Colors of fronts are chosen to be black to avoid confusion with chart data. As for the 


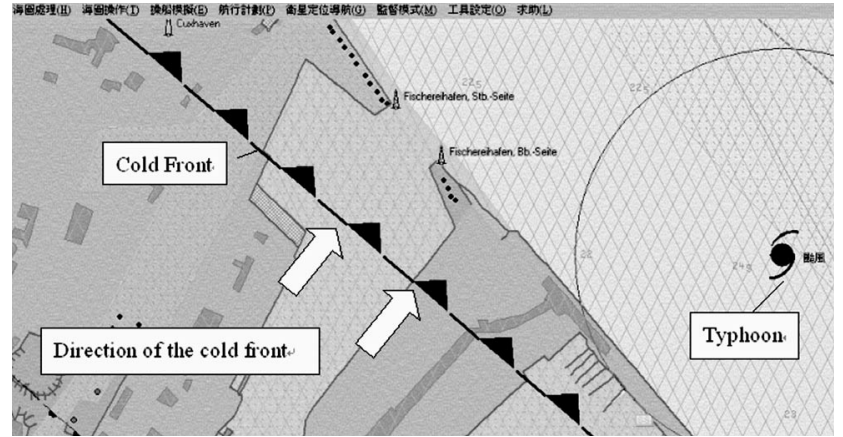

Fig. 1. Screen capture of the test implementation of meteorological data in ECDIS.

tropical cyclone, the actual point symbol to be used can be selected according to its geo-location (north or south hemisphere) and strength. Name of the cyclone is encoded as the object name, which can be displayed if required.

\section{CONCLUSION}

The incorporation of meteorological and oceanographic information into ECDIS will make it a more versatile tool to make navigation more efficient and safer as a result. The integration proposed in this paper has been preliminarily proved to be highly feasible. However, further investigation and developments are required to gain the maximum benefit from the integration.

\section{ACKNOWLEDGMENT}

The author would like to thank Mr. K. C. Dai for his assistance in programming.

\section{REFERENCES}

1. IMO Resolution A.817(19) on Performance Standards for ECDIS, adopted in Nov. 1995.

2. IHO S57 Transfer Standards for Digital Hydrographic Data, 3rd ed., Nov. 1996.

3. IHO S52 Specifications for Chart Content and Display Aspects of ECDIS.

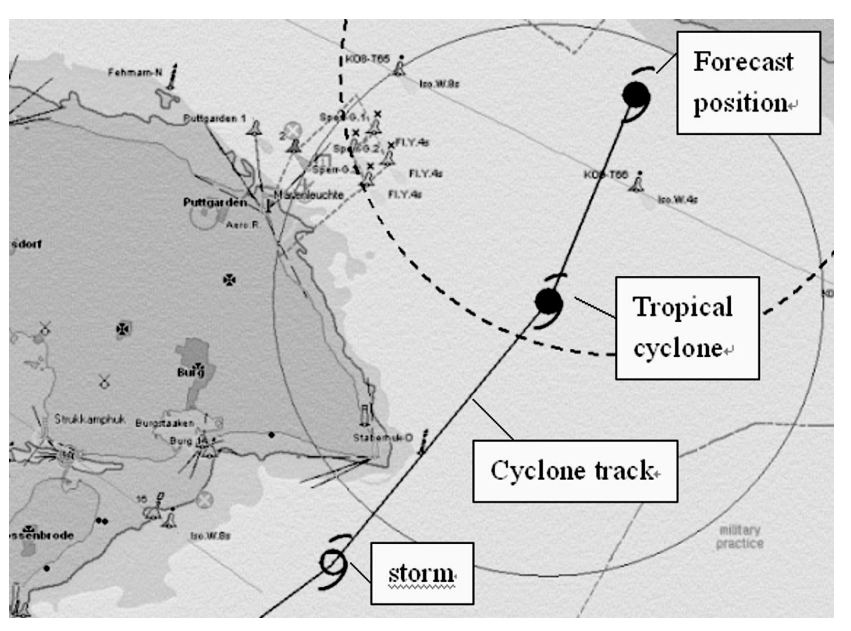

Fig. 2. Test implementation of tropical cyclones in ECDIS.

\section{ECDIS 電子海圖系統整合氣象資訊 之設計與試驗}

$$
\text { 張 淑 淨 }
$$

國立台灣海洋大學導航與通訊系

$$
\text { 摘 要 }
$$

在電子海圖顯示與資訊系統(ECDIS) 中整合氣 象與海洋測量資訊已成爲國際海事組織、國際海測組 織與世界氣象組織共同關切的主要議題。這項整合將 使ECDIS此一航海決策支援工具更能有效地提升航行 安全與效率。本文首先從目前全球海上遇險與安全系 統(GMDSS)所提供的海事安全資訊中, 確認出與航 行安全有關的海象資訊, 並參考ECDIS相關標準, 針 對氣象資訊與ECDIS 整合時氣象資料之編碼與傳輸、 資訊更新、符號與顯示方式、以及氣象資料與ECDIS 航路計劃、航路監視等功能整合應用等問題提出具體 建議。其可行性已在自行設計之ECDIS系統上, 以颱 風及鋒面爲例, 獲得初步證實。 